\title{
Recent Changes in Regulatory Development of Interreligious Marriage and Children's Rights Based on Justice Perspective in Indonesia
}

\author{
Setiyowati
}

\section{Universitas 17 Agustus 1945 Semarang, Indonesia}

\begin{abstract}
The issue of this study is the marriage registration with or on the basis of a court decision as referred to in Law Number 24 of 2013 concerning Population Administration is valid according to Law No. 1 of 1974 regarding Marriage. The Marriage Law is also one of the bases for the formation of the Population Administration Law. Bearing in mind that the Population Administration Act does not regulate further about how the procedure of marriage between people of different religions occur so that the terms and procedures and prohibition of marriage in the Marriage Law remain in force. Based on the above background, problems can be formulated to analyze marital regulations in the Marriage Law not yet fully based on the value of justice and its reconstruction. The findings show that the Reconstruction of marriage regulations in the perspective of the Marriage Law based on justice values can be carried out by reconstructing the provisions of articles governing the validity of marriages, which in their implementation or in their application do not indicate or provide a sense of justice for some people who will carry out marriages, particularly those related to the practice of interfaith marriages.
\end{abstract}

Keywords: Population Administration, Marriage Law, Indonesia, Legal Reconstruction, Interreligious marriage, children's right.

\section{INTRODUCTION}

The birth of Law No. 1 of 1974 concerning Marriage (hereinafter the Marriage Law) is based on the desire of the Indonesian people to have a national marriage regulation that applies to all classes of Indonesian society, but this does not mean that this Law has regulated all aspects related to marriage, because, in reality, the implementation of this Law is problematic for some groups of people, such as interfaith marriages (Pompe, 1988; Lukito, 2008). Interfaith marriages are marriages made by couples (men and women) who have different religions. The Marriage Law does not regulate interfaith marriages, so there is no room for interfaith couples to do marriages in Indonesia or in other words interfaith marriages are considered illegal (Connolly, 2009; Suadi, 2019). The only article that regulates the validity of a marriage is Article 2 of the Marriage Law. The formulation of article 8 (f) of the Marriage Law also gives rise to different interpretations of the sentence which is related by religion or applicable regulations because the sentence can be interpreted as having familial relations and not because of the prohibition of religious differences. As a consequence of illegitimate marriages, interfaith marriages cannot be registered because the Civil Registry Office refuses to take notes.

*Address correspondence to this author at the Universitas 17 Agustus 1945 Semarang, Indonesia; E-mail: setiyowati.untag@gmail.com
On the other hand, the Marriage Law concerning Marriage also regulates marriages conducted overseas (Article 56) and mixed marriages (Article 57) (Seo, 2013). The issue is whether the marriage registered with or on the basis of a court decision as referred to in article 35 (a) of Law Number 24 of 2013 concerning amendments to Law Number 23 of 2006 concerning Population Administration is valid according to the Marriage Law. Bearing in mind that the Population Administration Act (Population Administration) does not regulate further about how the procedure of marriage between people of different religions occur so that the terms and procedures and prohibition of marriage in the Marriage Law remain in force. The Marriage Law is also one of the bases for the formation of the Population Administration Law. Based on the above background, problems can be formulated to analyze marital regulations in the Marriage Law not yet fully based on the value of justice and its reconstruction.

\section{LITERATURE REVIEW}

\subsection{Marriage in Indonesian Law}

According to the provisions of Article 2 paragraph (1) of the Marriage Law, a marriage is legal if it is carried out according to the law of each of its religions and beliefs. This article refers first to the law of each religion and its beliefs for each of its adherents, according to the explanation of Article 2 of Law No. 1 of 1974 concerning Marriage there is no marriage outside the law of each religion and that belief, in accordance 
with 1945 Constitution (Ramulyo, 1996). Furthermore, in Article 2 paragraph (2) of the Marriage Law, it is said that each marriage is recorded according to the applicable laws and regulations. There are some marital regulations before the enactment of Law No. 1 of 1974 concerning Marriage (Mubarok, 2015; Munfarida, 2012; Jones et al., 2009). In-Law Number 22 of 1946, it is stipulated that marriage is legal if carried out according to the Islamic religion which is overseen by the Married Registrar appointed by the Minister of Religion or an employee appointed by him (Katz, \& Katz, 1975). These provisions are accompanied by sanctions for those who commit violations that charge a fine whoever engages in a marriage contract with a woman, not under the supervision of the guardian.

In terms of the explanation of the Marriage Law, the interpretation that tends to be in accordance with the wishes of the state is the second interpretation, namely structural interpretation. Explanation regarding the legality of marriage and marriage registration is not separated as contained in the body of the Marriage Law, namely that marriage is legal if it is done according to each religion and belief and each marriage must be recorded according to statutory regulations applicable. The tendency to make registration one of the conditions for marriage is reinforced again in Government Regulation Number 9 of 1975 concerning the Implementation of the Marriage Law. In Government Regulation No. 9/1975 concerning the Implementation of the Marriage Law, several aspects are stipulated (Aini, 2008).

First, the recording of marriages carried out according to the religion of Islam, carried out by marriage registration employees. Second, every person who is going to have a marriage notifying his wishes to the marriage registrar at the wedding venue will take place at least 10 working days before the marriage takes place, the notice can be made verbally or in writing by the person concerned, parents, or their representatives. Third, the marriage takes place before the marriage registrar and is attended by two witnesses (Article 10 paragraph 3 Gov. Reg. No. 9 of 1975).

For those who carry out marriages according to their religion and beliefs other than Islam, marriage registration is carried out by the marriage registrar at the civil registry office as referred to in various laws regarding marriage registration. Article 56 paragraph 1 of the Marriage Law states that "marriages that take place outside Indonesia between two Indonesian citizens or an Indonesian citizen and a foreign national are legal if carried out according to the law in force in the country where the marriage is carried out and for Indonesian citizens do not violate the provisions of this Act". Furthermore, Article 56 paragraph 2 of the Marriage Law states that within 1 (one) year after the husband and wife return to Indonesian territory, their marriage certificate must be registered at the Marriage Registration Office of their residence (Nisa, 2018). Referring to Article 2 paragraphs (1) and (2) and Article 56 paragraphs (1) and (2) of the Marriage Law, it is expressly stated that the legality of marriage in Indonesia is based on religion. While recording is an administrative aspect for the sake of order as a citizen. On the other hand, marriages outside Indonesia that only pay attention to civil aspects, then the legality of the marriage is solely based on agreement and so on administratively recorded.

\subsection{Interreligious Marriage in the Perspective of Marriage Law}

Based on the provisions of Article 66 of the Marriage Law, for all marriages and everything related to marriage based on this Law, then with the enactment of this Law the provisions stipulated in the Civil Code (BW), Christian Indonesian Marriage Ordinance (Huwelijks Ordonantie Christen Indonesiers S. 1933 No. 74), Mixed Marriage Regulations (Regeling op de gemengde Huwelijken S. 1898 No. 158), and other regulations governing marriages to the extent stipulated in this Law, is declared invalid.

In a contradictive manner, it can be interpreted that the provision is still valid as long as it is not regulated in the Marriage Law and is not a regulation as a whole. With regard to interfaith marriages, in principle, the Marriage Law, the system does not explicitly regulate even there are no laws governing interfaith marriages, which are regulated in the Marriage Law that is only marriage mixed, as contained in Article 57 (Koschorke, 2019). What is meant by a mixed marriage is a marriage between two people who in Indonesia are subject to different laws because of different nationalities or different citizenship.

From the understanding of mixed marriages, it can be said that mixed marriages are not the same as interfaith marriages, in other words, mixed marriages are not interfaith marriages because interfaith marriages are marriages made by two people of different religions or beliefs (Cammack, 2009; Çiğdem, 2015). If it is reviewed in the provisions of Article 2 (1) 
of the Marriage Law that the validity of a marriage is if it is carried out according to the law of each of his Religions and Beliefs. This means that the Lawfully relinquishes Religion and Religion has an important role in marriage. Furthermore, Article 10 of Government Regulation No. 9/1975 states that a marriage is only valid if it is performed in the presence of a registrar and is attended by two witnesses and the marriage procedure is carried out according to the law of each religion and belief.

\section{RESULTS}

The Marriage Law which is a positive law, which applies to Indonesian citizens, turns out to display a dual nature in terms of the legality of marriages. First, there is a regulation stating that the validity of a marriage is based on religion and beliefs. Secondly, there is an assumption that the legality of marriage can be based on the laws of other countries even though it is not based on religion.

The first trait makes it difficult to hold interfaith marriages, while the second trait, makes it possible to hold interfaith marriages. The consequence of the enactment of these provisions is the existence of the practice of pretending to convert to facilitate the process of marriage in the country (is one way to do legal smuggling), and the practice of marriage outside the territory of Indonesia (marriages conducted abroad) for Indonesian citizens who are financially capable (Parker, Hoon, \& Raihani, 2014; Wahyuni, 2017). These provisions are considered to cause injustice for some people, which is caused by the provisions of the Marriage Law concerning marriages that are not consistent in regulating marital legitimacy issues. The purpose of the law is to provide welfare, happiness including giving human justice, so that if the law does not guarantee legal protection for humans, then the law must be changed (Çiğdem, 2015). Law is for humans, not humans for law, so the law is always in the status of law in the making. The law does not exist for itself and is not final, so if the law does not guarantee legal protection, changes must be made. Likewise, because the application of the Marriage Law in its implementation creates ambiguity, uncertainty and injustice for the community so for the realization of a sense of justice for all Indonesian citizens, the provisions or formulations. The formulation of the Marriage Law, in particular, which regulates the validity of a marriage, must be reconstructed or restructured.

In carrying out this reconstruction, it must be carried out with due regard to the values that live in the community, including the religious values of the Indonesian people. In other words, in carrying out reconstruction of the Marriage Law, particularly with regard to articles or provisions that are considered to trigger the occurrence of interfaith marriage practices, they must consider the sense of justice and law that lives in the community (Karsayuda, 2006; Wahyuni, 2014). Reconstruction or rearrangement is seen as legal development, that is, as an effort to build a legal order that includes the substance component, the institutional component, and the legal culture component which is the attitude and behavior of the community members. The Marriage Law is a written statutory regulation, which contains generally binding legal norms and is established or established by a state institution or authorized official through the procedures stipulated in statutory regulations.

According to Article 5 of Law Number 12 of 2011 that informing legislation must be done based on the principle of the formation of good legislation, which includes clarity of purpose; appropriate institutional or forming authority; conformity between type, hierarchy, and material content, implementability, clarity of formulation, and openness The provisions of Article 2 (1) governing the validity of marriages have not fulfilled the provisions in the formation of legislation in accordance with Article 5 of Law Number 12 of 2011 specifically concerning the clarity of formulation, so the provisions of Article 2 (1) of the Marriage Law needs to be reconstructed so that the formulation of the provisions of Article 2 (1) of the Marriage Law is clearer in regulating the validity of the marriage. Moreover, for the sake of establishing legal certainty and in order to avoid differences of opinion due to various different interpretations in interpreting the formulation of Article 8 (f), the formulation of Article 8 (f) needs to be reconstructed so that the formulation is clearer in providing limitations or provisions about prohibitions for the whole community.

In terms of the status of children in an interfaith marriage, a child is said to be a legitimate child according to Article 42 of the Marriage Law if born in or as a result of a legal marriage. As a result of interfaith marriage laws against children, legally positive children born outside of marriage only have a civil relationship with their mother and mother's family. Thus, children outside of marriage according to the law in terms of the Marriage Law and Compilation of Islamic Laws do not have civil relations with their father and his father's family. Consequently, the child outside of marriage cannot be the heir of his father. During this time, 
religious differences are seen as one of the factors that hinder or prevent a child from inheriting from his parents, but that view is now beginning to be abandoned. The court, in particular, the Supreme Court of the Republic of Indonesia with its jurisprudence Number: 368 K/AG/1995 dated July 16, 1998, and the jurisprudence of the Supreme Court of the Republic of Indonesia Number: $51 \mathrm{~K} / \mathrm{AG} / 1999$ dated September 29,1999 , which among other reasons stated that nonbiological children were not heirs but entitled to get part of the inheritance based on mandatory heirs, besides that the Constitutional Court through its decision No. 46/PUU/VII/2010 has made a progressive decision that "children born out of wedlock have a civil relationship with their mother and her mother's family as well as with men as their father who can be proven based on science and technology and/or other evidence according to the law have blood relations including civil relations with his father's family so that it can be an opportunity for children born of interfaith marriages to inherit as long as it can be scientifically proven by the truth of their lineage.

Provisions in Article 56 (1) of the Marriage Law which originally stated that a marriage held outside Indonesia between two Indonesian citizens or an Indonesian citizen and a foreign citizen is legal if carried out according to the applicable law in the country where the marriage took place and for Indonesian citizens not violating this Law, is reconstructed into "a marriage that takes place outside Indonesia between two Indonesian citizens or an Indonesian citizen with a foreign citizen is legal if carried out according to applicable law in the country where the marriage takes place and for Indonesian citizens is considered valid if the marriage is conducted according to religious law and beliefs.

\section{CONCLUSION}

The results showed that marriage regulations in Law No. 1 of 1974 are not yet fully based on the value of justice. This can be seen from the provisions stipulated in the Marriage Law, specifically relating to the validity of a double marriage as contained or regulated in Article 2 (1) and Article 2 (2), as well as in Article 56 (1) and Article 56 (2) of the Marriage Law. On the one hand, the marriage must be based on religion and beliefs, while on the other side, another legal marriage can be based on the laws of other countries even though not based on religion and beliefs. In other words, there is a difference in treatment between them (interfaith marriage partners) who will make their marriage in Indonesia and those (interfaith couple) who will have their marriages outside of Indonesian territory. The reconstruction of marriage regulations in the perspective of the Marriage Law based on justice values can be carried out by reconstructing the provisions of articles governing the validity of marriages, which in their implementation or their application do not show or provide a sense of justice for some people who will carry out marriages, especially those related to the practice of interfaith marriages.

\section{REFERENCES}

Aini, N. (2008). Inter-religious marriage from socio-historical Islamic perspectives. BYU L. Rev., 669.

Cammack, M. (2009). Legal aspects of Muslim-non-Muslim marriage in Indonesia. In Muslim-Non-Muslim Marriage: Political and Cultural Contestations in Southeast Asia, 102-138. Singapore: Institute of Southeast Asian Studies. https://doi.org/10.1355/9789812308221-007

Çiğdem, R. (2015). Interfaith marriage in comparative perspective. Acta Orientalia, 68(1), 59-86. https://doi.org/10.1556/AOrient.68.2015.1.4

Connolly, J. (2009). Forbidden Intimacies: Christian-Muslim Intermarriage in East Kalimantan, Indonesia. American ethnologist, 36(3), 492-506. https://doi.org/10.1111/j.1548-1425.2009.01175.x

Jones, G. W., Leng, C. H., \& Mohamad, M. (Eds.). (2009). Muslimnon-Muslim marriage: Political and cultural contestations in Southeast Asia. Institute of Southeast Asian Studies.

Karsayuda, M. (2006). Perkawinan beda agama: menakar nilai-nilai keadilan Kompilasi hukum Islam. Yogyakarta: Total Media.

Katz, J. S., \& Katz, R. S. (1975). The new Indonesian marriage law: a mirror of Indonesia's political, cultural, and legal systems. Am. J. Comp. L., 23, 653. https://doi.org/10.2307/839240

Koschorke, J. (2019). Legal Pluralism in Indonesia: The Case of Interfaith Marriages Involving Muslims. In Legal Pluralism in Muslim Contexts (pp. 199-229). Brill. https://doi.org/10.1163/9789004398269010

Lukito, R. (2008). The enigma of legal pluralism in Indonesian Islam: the case of interfaith marriage. Journal of Islamic Law and Culture, 10(2), 179-191.

Mohd, R. (1996). Idris, Hukum Perkawinan Islam: Suatu Analisis dari Undang-Undang No. 1 Tahun 1974 dan Kompilasi Hukum Islam.

Mubarok, J. (2015). Pembaruan hukum perkawinan di Indonesia. Simbiosa Rekatama Media.

Mulia, S. M. (2009). Promoting gender equity through interreligious marriage; Empowering Indonesian Women. Muslim-nonMuslim marriage: political and cultural contestations in Southeast Asia, ISEAS, Singapore, 255-82. https://doi.org/10.1355/9789812308221-012

Munfarida, E. (2012). Political Backdrop of the Indonesian Marriage Law of 1974. Al-Manahij: Jurnal Kajian Hukum Islam, 6(1), 129-142. https://doi.org/10.24090/mnh.v6i1.593

Nisa, E. F. (2018). The bureaucratization of muslim marriage in indonesia. Journal of Law and Religion, 33(2), 291-309. https://doi.org/10.1017/jlr.2018.28

Parker, L., Hoon, C. Y., \& Raihani. (2014). Young people's attitudes towards inter-ethnic and inter-religious socializing, courtship 
and marriage in Indonesia. South East Asia Research, 22(4), 467-486.

https://doi.org/10.5367/sear.2014.0230

Pompe, S. (1988). Mixed marriages in Indonesia: Some comments on the law and the literature. Bijdragen tot de taal-, land-en volkenkunde/Journal of the Humanities and Social Sciences of Southeast Asia, 144(2), 259-275. https://doi.org/10.1163/22134379-90003296

Rahardjo, S. (2009). Hukum Progresif; Sebuah Sintesa Hukum Indonesia. Yogyakarta: Genta Publishing.
Seo, M. (2013). Falling in love and changing gods: Inter-religious marriage and religious conversion in Java, Indonesia. Indonesia and the Malay World, 41(119), 76-96. https://doi.org/10.1080/13639811.2012.750104

Suadi, A. (2020). The role of religious court in prevention underage marriage. Jurnal Hukum dan Peradilan, 9(1), 116-131. https://doi.org/10.25216/jhp.9.1.2020.116-131

Wahyuni, S. (2014). Politik Hukum Perkawinan dan Perkawinan Beda Agama di Indonesia. Jurnal Pusaka, 1(2).

Wahyuni, S. (2017). Nikah Beda Agama: Kenapa ke Luar Negeri?. Pustaka Alvabet.

Received on 02-05-2021

Accepted on 02-06-2021

Published on 02-07-2021

https://doi.org/10.6000/1929-4409.2021.10.133

(C) 2021 Setiyowati; Licensee Lifescience Global.

This is an open access article licensed under the terms of the Creative Commons Attribution Non-Commercial License (http://creativecommons.org/licenses/by-nc/3.0/) which permits unrestricted, non-commercial use, distribution and reproduction in any medium, provided the work is properly cited. 